\title{
COVID-19 Pandemic in Libya: What do we know so far?
}

\section{Qais Gasibat ${ }^{a}$, Musab Gasibat ${ }^{\mathrm{b}}$}

a PT, BSc, MSc, Lecturer at Faculty of Medical Technology, Misurata, Libya and PhD Student at University Putra Malaysia (UPM)

${ }^{\mathrm{b}}$ BDS, President of the Misurata University Students' Union

The first Coronavirus Disease 2019 (COVID19) case was officially confirmed in Tripoli, Libya on 24 Mar 2020 which confirmed the spread of the pandemic to Libya. ${ }^{1}$ Libya was extremely vulnerable during the pandemic because it was already affected by the Libyan Civil War. This pre-existing dire humanitarian condition in the country had destroyed the healthcare infrastructure of the nation, leaving it susceptible to the pandemic. Libya has been going through the collapse of the healthcare system even before the spread of the pandemic in the country. ${ }^{2}$ Steps such as closure of markets, businesses, and schools have been taken by the Government of National Accord (GNA) to control the spread of COVID-19 which further stressed the fragile economy. Libya's first confirmed COVID-19 case arose from a 73-year-old man who came back to Libya from Saudi Arabia on 5 March 2020. ${ }^{1}$ Since then, the number of cases has increased steadily, and, by April 16, the number of confirmed COVID-19 cases in Libya rose to 49. This was considered a relatively small number, compared with countries in the region and in the world. Up to that time, only 1 death had been reported of a woman who tested positive for SARS CoV-2. The low number of cases in April and May was thought to be due to government efforts, few airports, cool climate, BCG vaccination, limited testing kits, or cultural aversion to getting tested. ${ }^{3}$

Eastern Libya confirmed its first case on 7 April 2020. However, by that time further cases had been confirmed in the country, mostly in Western Libya. A 24-hour curfew was imposed for 10 days by the GNA on 17 April 2020. ${ }^{3}$ Some 51 cases were found during April which made the total number of cases to be 61 . The number of recovered patients increased to 18 , while three patients died. There were 40 active cases at the end of the month.

In May, 95 new cases were observed making the total number of confirmed cases to be 156 . The death toll increased to 5. At the end of the month, there were 99 active cases in which the number of recovered patients increased from 34 to 52 .

However, in June, within two weeks, the cases literally doubled. Increased armed conflict included targeting of healthcare facilities, and this made the medical teams struggle to respond. ${ }^{4}$ As of 7 June 2020 , there were 270 confirmed cases of COVID-19 reported in Libya, including five deaths, and a total of 53 people had recovered. On 21 June 2020, the Libyan National Centre for Disease Control (NCDC) reported 571 confirmed cases, including 10 COVIDrelated deaths, a total of 98 people had recovered. In response to an increasing number of confirmed cases, the GNA announced a curfew from 8 p.m. to 6 a.m., starting 17 June 2020 for 10 days, with a 24hour curfew on weekends with no travel allowed between cities, as confirmed cases increased to 713 . There were 668 new cases in June, raising the total number of confirmed cases to 824. The death toll rose to 24 . The number of recovered patients grew to 209 , leaving 591 active cases at the end of the month.

In July, the number of confirmed COVID-19 cases in Libya more than quadrupled, increasing from 824 to 3,621 confirmed cases, with 2867 new cases. At the end of that month, the number of active cases was 2,929 where the number of recovered patients increased to 618 whilst the death toll increased to 74. The majority of new COVID-19 cases were identified in Tripoli, Misurata and Sebha. 
In August, the number of confirmed COVID19 cases increased rapidly, from 3,621 at the end of July to 14,624 by the end of August. The new cases were detected after the NCDC received 1,481 suspected samples, adding 23 more patients who recovered and five more who died, increasing the total recoveries to 1,333 and the total death toll to 231.

On 19 September 2020, the NCDC reported 715 COVID-19 cases, and the total confirmed cases in the country exceeded 27,949 . The total number of COVID-19 cases in Libya by end of September was 32,364 , including 18,128 recoveries and 520 deaths, the center confirmed. ${ }^{5}$ (Figure 1)

Figure 1. Total Confirmed COVID-19 cases in Libya Through September 2020

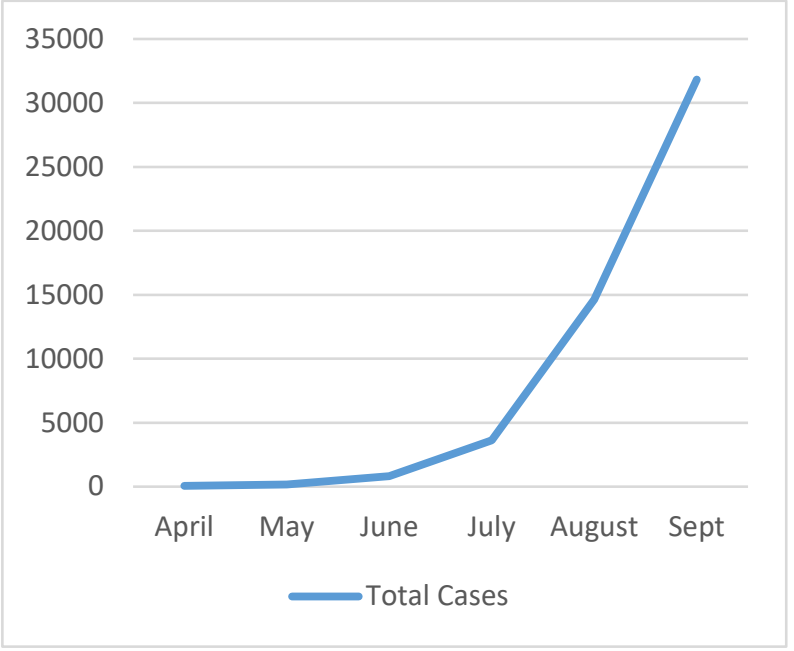

The Director of NCDC warned that the number of new confirmed cases of COVID-19 in the capital, Tripoli, and the city of Misurata, was on the increase. The number of cases requiring medical attention in Tripoli and Misurata has also risen. According to the Director of the NCDC, the laboratories at the centre carried out 1,000 to 1,500 tests per day but should have been testing 10,000 people each day. COVID19 was threatening both the health, livelihoods, and protection needs of Libyans, refugees, and migrants with a rising number of confirmed cases.

The majority of Libya's municipalities have officially spiked from phase 3 to phase 4 of the pandemic, leading to a massive increase of infected and suspected cases which makes it difficult to track and control the spread of the pandemic.

By not following the guidelines set by the NCDC, the number of infected cases will continue to rise due to the negligence of the public regarding social distancing which is an essential strategy for controlling any infectious disease, especially if the disease is a respiratory infection. In our opinion, failing to wear masks, attending social gatherings, and not obeying the guidelines set by the NCDC is the main concern because this virus is transmitted by droplets and close contact. Many people have asymptomatic or pre-symptomatic infections, and if they wear a face mask, this can prevent droplets that carry the virus from escaping and infecting others. ${ }^{6}$ The phrase "you protect me and I protect you" is very apt in this situation.

\section{References}

1. Daw MA. Preliminary epidemiological analysis of suspected cases of corona virus infection in Libya. Trav Med Infect Dis.1 2020 Mar 20;35:101634. https://doi.org/10.1016/j.tmsod.2020.101634

2. Daw MA. Corona virus infection in Syria, Libya and Yemen; an alarming devastating threat. Trav Med Infect Dis. 2020 Apr 2;101652. https://doi.org/10.1016/j.tmaid.2020.101652

3. Gasibat Q, Raba AA, Abobaker A. COVID-19 in Libya: fewer cases so far. Any speculations? Disaster Med Public Health Prep. 2020 May 29:1-2. https://doi.org/10.1017/dmp.2020.177

4. Aljazeera News. Libya: Tripoli hospital attacked by 'Haftar's missiles'. 14 May 2020. [Internet] Available from: https://www.aljazeera.com/news/2020/05/libyatripoli-hospital-attacked-haftar-missiles200514110305740.html

5. National Centre for Disease Control-Libya. Coronavirus (COVID-19) Situation by (who).

[Internet] Available from: https://ncdc.org.ly/Ar/situation-by-who/

6. World Health Organization. Advice on the use of masks in the context of COVID-19: interim guidance, 2020 June 5 [Internet]. World Health 
Organization; 2020. Available from:

https://apps.who.int/iris/handle/10665/332293

Submitted 2 Sept 2020, accepted 12 Sept 2020, revised 27 Sept 2020, published 9 Nov 2020

Competing Interests: None declared.

Correspondence: Qais. Faculty of Medical Technology, Misurata, Libya drqaiss9@gmail.com

Cite this article as: Gasibat Q, Gasibat M. COVID-19 Pandemic in Libya: What do we know so far? Christ J for Global Health. Nov 2020; 7(4):44-46. https://doi.org/10.15566/cjgh.v7i4.451

(C) Authors. This is an open-access article distributed under the terms of the Creative Commons Attributior License, which permits unrestricted use, distribution, and reproduction in any medium, provided the original author and source are properly cited. To view a copy of the license, visit http://creativecommons.org/licenses/by/4.0/ 